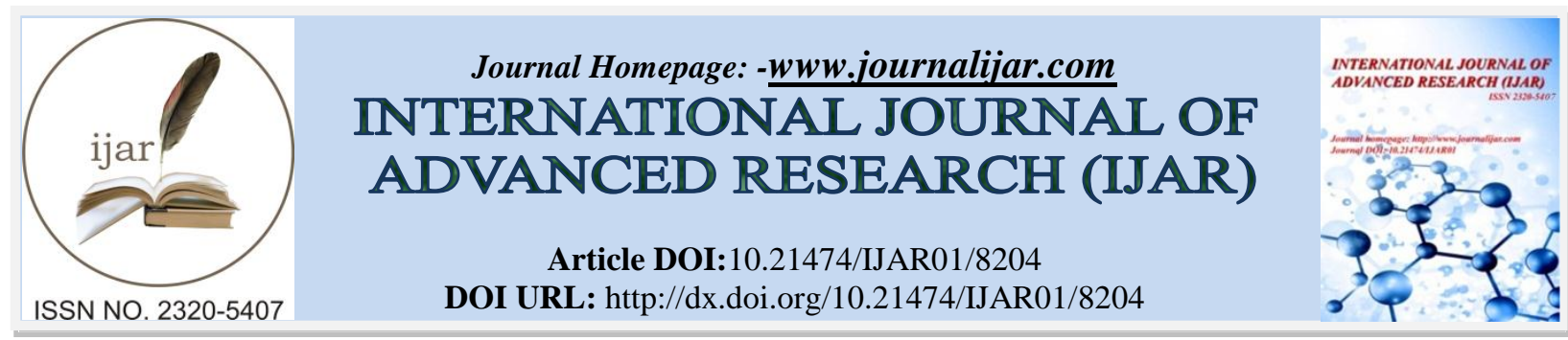

RESEARCH ARTICLE

\title{
WATTPAD.COM: ENHANCING WRITING SKILLS IN ESL CLASSROOM.
}

\author{
Nurul Syifa Binti Abdul Rahman ${ }^{14}$, Nurul Akmal Amirah Binti Sarudin ${ }^{24}$, Nurul Hanani Binti Shamsudin ${ }^{34}$ \\ and Melor Md Yunus ${ }^{4}$. \\ 1. Sekolah Jenis Kebangsaan Cina Bahau. \\ 2. Sekolah Jenis Kebangsaan Cina Sang Lee. \\ 3. Sekolah Kebangsaan Putrajaya Presint 11(2). \\ 4. Faculty of Education, Universiti Kebangsaan Malaysia (UKM), 43600 Bangi, Selangor, Malaysia.
}

\section{Manuscript Info}

...........................

Manuscript History

Received: 12 October 2018

Final Accepted: 14 November 2018

Published: December 2018

Key words:-

Website-based Language Learning, Wattpad.com, Writing skills, Corrective Feedback, Motivation.

\section{Abstract}

This study pinpoints the integration of web-based language learning (WBLL) and writing skills in the ESL classroom. Current research shows that WBLL places a great deal of improvement in reading and speaking skills. However, this paper aims to find out if WBLL can be used as a platform to assign writing activities and provide corrective feedback among the upper primary school students in Putrajaya, Raub, Pahang and Jempol, Negeri Sembilan. Data is collected and analyzed descriptively through the pre-post test score, formative tasks, and group interview. The main findings suggested that a) integration of the writing modules developed and Wattpad.com makes WBLL possible in the primary ESL classroom as participants constantly showed improvement in writing skills through the formative tasks and pre-post test, b) participants improve writing skills from the corrective feedback given directly in the process of writing and c) participants view WBLL positively in learning writing skills. In conclusion, it is proven that the use of Wattpad.com able to gauge the writing performance as well as positive attitudes towards WBLL.

Copy Right, IJAR, 2017,. All rights reserved.

\section{Introduction:-}

Writing is an essential skill to be developed as a part of language learning. This skill requires learners to master the process of writing from word level up until to text level including the choice of words, vocabulary, grammar content and etc. However, Yunus (2018) stated that in order to enable students to become a better communicator, we should perhaps go beyond everything be it grammar, vocabulary and pronunciation and that teachers should leave behind the conventional method and make changes by communicating effectively in international settings instead. This suggested that the educators need to maximize learner's potential in writing not only using the conventional method but including the elements of technology in their daily learning process which aims to enable learners to have a meaningful learning process as it increases their motivation as well as helping them to improve their skill in an interactive way.

In the Malaysian context, writing skill is one of that pupils should master by the end of year 6-primary schooling as outlined in the DSKP. It is aimed to produce competent writers by achieving band A2 as parallel in the latest

Corresponding Author:-Melor Md Yunus.

Address:-Universiti Kebangsaan Malaysia (UKM), 43600 Bangi, Selangor, Malaysia. 
Common European Framework (CEFR) aligned curriculum; 'Able to describe in simple terms aspects of his/her background, immediate environment and matters in areas of immediate need'. Compliment to that, Malaysian Education Blueprint (2013-2025) in Wave 1 advocates the integration of salient technology as an educational approach in meeting $21^{\text {st }}$-century challenges. Thus, WBLL is seen as one of the suitable approaches to teach writing skill.

Based on that, a preliminary investigation has been conducted with Peninsular Malaysia primary school teachers from Putrajaya, Negeri Sembilan and Pahang to discover the problem faced by them in teaching writing skill. Based on the result, it has been identified that there are numbers of main areas of concerns for teachers including delayed feedback given in writing lessons, the use of conventional and didactic teaching method in teaching writing skill which contributes to the learners' passive attitude towards writing in English. This problem is assumed to arise because teachers do not have sufficient training on how technology can be utilized in language learning. This is supported by Kamel (2016), where studies indicate that distance and traditional education could be as effective when the method and technology used are appropriate and when there are student-to-student interaction and timely teacher to student feedback. ,

Therefore, this paper aims to investigate whether Web-based language learning (WBLL); Wattpad.com can be used to enhance writing skills in ESL classroom, to explore the use of corrective feedback as well as the students' perception towards the use of WBLL in teaching writing.

\section{Literature Review:-}

Web-based Language Learning:-

Web-based Language Learning is gaining worldwide recognition and credit in the language classroom. There are many improvements in students' performance that can be found when WBLL is implemented in the English classroom. A review on speaking lesson by Cong-Lem (2018) stated that, web-based language learning generally has a positive impact on learners' L2 speaking proficiency as well as on their affective factors. In teaching vocabulary, a research conducted by Gorjian (2012) who used quasi-experimental in his research shows that retention of the vocabularies was better in WBLL group compared to those who did not receive the learning vocabulary through WBLL.

There is limited research conducted on WBLL towards writing skills. For example, a study on Iranian students conducted by Mashhadizadeh and Rezvani in 2015. The results of the study show that the learners' attitude towards the WBLL approach was positive in the areas of the helpfulness of the approach, improvement in their confidence and writing proficiency, as well as the sub-field of word phrase. However, in the Malaysian context, there is an inadequate study conducted between WBLL and teaching writing which lead to the research of this study.

Moreover, WBLL helps in motivating people in language learning. In a research conducted by Nosrati (2015), it shows that students are having positive towards using the computer in language instruction because computers make them more efficient in their lives. This can also be supported by Cong-Lem(2018) who found that WBLL can help to reduce L2 learners learning and making them become more active, motivated language learners. Therefore, it is suggested the use of WBLL may encourage students' perception in learning the language.

\section{Corrective Feedback:-}

Chaudron (1988) defined corrective feedback as 'any teacher behavior following an error that minimally attempts to inform the learner the fact of the errors, hence prompt self-correction and may correct errors in ways learners may not realize that responses are needed. Corrective feedback can be orally and written, in which it can be used to correct a range of errors, including linguistics and pragmatic errors. Su and Tian (2016) elaborated the concept of corrective feedback in ESL Classroom by comparing three different schools of thoughts in addressing corrective feedback. For instance, Zhang Kai (2015) in Su and Tian (2016) believed that that language is acquired by cofunction between language learners and the environment through the interaction in which described as the focus-onform theory includes three hypotheses: Interaction Hypothesis, the Output Hypothesis, and the Noticing Hypothesis. These hypotheses are proven to be useful in teaching language learning as it provides immediate feedback to support L2 learning through various types of corrective feedback like explicit feedback and recast. These types of corrective feedback allow the educator to keep track of the students' progress, especially in learning writing skills. Alavi (2014) further supported the notion by claiming that teachers' mediation in the form of explicit feedback was the most effective hint within the dynamic assessment parameter in L2 internalization of writing skills. Several studies 
have been conducted on written feedback in the Malaysian context using email and conventional pen-paper (Darus \& Subramaniam,2009; Yoke et al., 2013; Lee, 2014; Yunus, 2017). Although Yunus (2017) gathered that there is a positive impact on utilizing corrective feedback in Mobile Assisted language learning, however, there is lack of literature on how $\mathrm{CF}$ can be incorporated with Web-based language learning in teaching writing. Therefore, this paper attempts to focus on the direct written CF in the Wattpad.com platform as the process of writing takes place.

\section{Methodology:-}

This study used a mixed method design in which the researcher collected both quantitative and qualitative data. The selection for this study was based on purposive sampling from primary schools in three different states in Malaysia. The language proficiency is an intermediate level, however, has a strong inclination and positive attitude towards learning English.

The subsequent section describes the setting for the study, the participants involved, the intervention used as well as data collection procedures.

\section{Setting:-}

In this study, the English skills that will be the focus is writing skills. It is one of the skills that need to be master by all pupils before they graduated. This study was conducted in three different states which is Putrajaya, Pahang and Negeri Sembilan. The schools chosen for this study are all Sekolah Kebangsaan (SK). The duration of this study was 8 hours face-to-face hours conducted for four weeks. Students involved in the study twice a week lasting one hours each.

\section{Research Participants:-}

The participants of this study consisted of thirty 11 years old pupils. The demographics of the participants are shown below in Table 1.

\begin{tabular}{|l|l|l|}
\hline Demographic Attributes & \multirow{2}{*}{ Frequency } \\
\hline Location & Gender & \\
\hline \multirow{2}{*}{ Jempol, Negeri Sembilan } & Male & 5 \\
\cline { 2 - 3 } & Female & 5 \\
\hline \multirow{2}{*}{ Raub, Pahang } & Male & 5 \\
\cline { 2 - 3 } & Female & 5 \\
\hline Putrajaya & Male & 5 \\
\cline { 2 - 3 } & Female & 5 \\
\hline
\end{tabular}

\section{The Tool:-}

Wattpad.com is a platform where readers and writers can gather in just one social platform. It is able to form an internet community for pupils who want to publish new type of generated stories in different genres, including classics, general fiction, historical fiction, non-fiction, poetry, fanfiction, spiritual, humor, and teen fiction. Wattpad.com itself is aiming to create social communities around stories for both amateur and established writers. Researcher use this website and generate it into the classroom because the website itself is suitable to use in the classroom and research found that this platform will help to improve pupils in term of writing skills because it is interactive and fun, the feedback response that pupils will get is fast either from teacher or from their peers and thus it will boost pupils' confidence in writing and produce quality writing products.

\section{Research Procedures:-}

This section will discuss on the implementation of intervention. The implementation of the intervention is being summarized in the table below: 


\begin{tabular}{|c|c|c|}
\hline \multirow[t]{2}{*}{ TIMELINE } & \multicolumn{2}{|c|}{ CYCLE 1} \\
\hline & Activity & Frequencies (\%) \\
\hline $\begin{array}{l}\text { 3.9.2018 and } \\
6.9 .2018\end{array}$ & $\begin{array}{l}\text { Word (Spelling) } \\
\text { Shared Sensory Writing }\end{array}$ & 50 \\
\hline $\begin{array}{c}12.9 .2018 \\
\text { and } \\
14.9 .2018\end{array}$ & $\begin{array}{l}\text { Sentences } \\
\text { Chained Writing } \\
\text { Weekly Journal }\end{array}$ & $\begin{array}{l}25 \\
25\end{array}$ \\
\hline Total & \multicolumn{2}{|c|}{100} \\
\hline TIMELINE & \multicolumn{2}{|c|}{ CYCLE 2} \\
\hline & Activity & Frequencies (\%) \\
\hline $\begin{array}{l}\text { 18.9.2018 and } \\
\text { 21.9.2018 }\end{array}$ & $\begin{array}{l}\text { Paragraph } \\
\text { If we have the power } \\
\text { Informative writing }\end{array}$ & $\begin{array}{l}25 \\
25\end{array}$ \\
\hline $\begin{array}{l}\begin{array}{l}25.9 .2018 \\
\text { and } \\
28.12 .2018\end{array} \\
\end{array}$ & $\begin{array}{l}\text { Paragraph } \\
\text { Reflection } \\
\text { Weekly Jurnal }\end{array}$ & $\begin{array}{l}25 \\
25\end{array}$ \\
\hline Total & & 100 \\
\hline
\end{tabular}

Table 2:-above shows the activities that were carried out along with Wattpad.com. These activities were carried out simultaneously in three different school for 4 weeks consecutively. Each lesson will get one-hour face-to-face interaction and in a week, there will be two hours lesson regarding writing and the integration of Wattpad.com. There will be two cycle in this study in which in the first cycle, researcher only focus to help pupils in word level and sentence level. It is important for pupils to master these two levels first because if not the "meaning will be confused and muddled" (Diana, 2015). Then, for the second cycle, researcher move to the paragraph level. The weekly journal activity will be the indicator to look on whether pupils can improve their writing skills in term of writing a better longer version of writing product.

Data Collection and Analysis Method:-

This section would describe the data collection methods used; pre-post test, formative tasks, observation using checklist, field notes and a group interview. The data is analysed descriptively.

\section{Pre-post:-}

Pre-post test is administered prior the strategy's implementation. Pre-test is designed to serve as the prerequisite of the intervention, followed by post-test upon completing Cycle 1 to compare participant performance and to measure the degree of change occurring as a result of interventions (Frey,2018). Then, we administered a new post-test to observe the change score due the modification made to the strategy

\section{Formative tasks:-}

Formative tasks are administered in each session after the strategy's implementation. The results are recorded and examined to measure the participants' progression in every session. This would tell the effectiveness of the strategy implemented as Graham, Hiebert and Harris (2015) claimed that formative tasks is crucial to provide an on-going feedback of the learners' progression by critically reviewing the instructor's teaching efficacy.

\section{Observation using checklist:-}

Lia (2017) has said that checklist helps the observer to remain focused on key points by asking for the frequency, absence, or presence of specific events. We used the designated checklist to record the frequency counts of the correct responses while implementing the strategy. This is crucial to the data analysis to examine the pupils' responses while implementing the intervention.

\section{Group Interview:-}

Group interview is conducted to gain insight into the reactions of the children about a new learning tool or strategy (Mohajan, 2018). Hence, a set of interview questions is designed to probe the participants' introspection by critically reviewing their learning experience through the retrospective inquiry. This would confirm the effectiveness of the strategy implemented. 


\section{Result:-}

Result focusing on the implication of the innovation in teaching writing are presented here in three subsections. Firstly, the emerging data collected from the formative tests and pre-post test would be analysed to highlight the writing performance as well as the changes in quality of writing. Secondly, the effect of the intervention on corrective feedback is analysed based on the observation checklist. Thirdly, the perception towards the intervention in teaching writing.

\section{Writing skills:-}

This section presents the changes in participants' writing performance as well as the quality of writing through the formative tests.

\section{Writing performance:-}

This section presents the writing performance in using the intervention while learning writing skills.

Table 3 shows that the innovation has a positive impact on the students' performance in writing. The data tabulated in pre and post-test scores proves that the integration of web-based learning in learning writing is viable.

Table 3:- Pre-test and post-test scores.

\begin{tabular}{|c|c|c|c|}
\hline \multirow{2}{*}{ Participants/Schools } & \multicolumn{3}{|c|}{ Cycle 1 } \\
\cline { 2 - 4 } & $\begin{array}{c}\text { Mean pre-test (\%) } \\
{[\mathrm{a}]}\end{array}$ & $\begin{array}{c}\text { Mean post-test 1 (\%) } \\
{[\mathrm{b}]}\end{array}$ & $\begin{array}{c}\text { Mean improvement 1 } \\
{[\mathrm{b}]-[\mathrm{a}]}\end{array}$ \\
\hline S1 & 66 & 100 & 34 \\
\hline S2 & 66 & 83 & 17 \\
\hline S3 & 66 & 100 & 34 \\
\hline
\end{tabular}

Table 3 above shows the comparison of the scores obtained in pre-post-test Cycle 1. Mean score for the pre-test is $66 \%$ indicated that the performance of writing skills is relatively low. However, the mean score for participants' from S1 and S3 is 100\% in their post-test 1 which marked the highest improvement in the group with $34 \%$ change score. Besides, participants from S2 achieved $83 \%$ in the post-test 1 shows good progress with $17 \%$ change score. The writing performance is further observed by analyzing the formative test scores.

\section{$\underline{\text { Analysis of formative tasks }}$}

The analysis of the formative test scores for both cycles is presented in the Table 4 below.

Table 4:-Comparison of the mean score for both cycles

\begin{tabular}{|l|l|l|l|l|}
\hline Participants/Schools & $\begin{array}{l}\text { Mean score of Cycle } \\
1(\%) \\
\text { (a) }\end{array}$ & $\begin{array}{l}\text { Mean score of Cycle } \\
2(\%) \\
\text { (b) }\end{array}$ & $\begin{array}{l}\text { Mean score of } \\
\text { improvement }(\%) \\
\text { (b-a) }\end{array}$ & $\begin{array}{l}\text { Level of } \\
\text { Progression }\end{array}$ \\
\hline S1 & 88.6 & 94.3 & +5.7 & Good \\
\hline S2 & 88.6 & 94.3 & +5.7 & Good \\
\hline S3 & 94.3 & 100 & +5.7 & Good \\
\hline
\end{tabular}

Table 4 shows the mean improvement of both cycles. All participants from the three schools show good progress of 5.7\%. S1 and S2 progressed from 88.6\% in Cycle 1 to $94.3 \%$ in Cycle 2, and S3 showed progress from $94.3 \%$ to $100 \%$. Ultimately, there is none of the participants shows regression after implementing the intervention. Thus, it shows that the participants showed improvement in Cycle 2 signifies that the intervention able to enhance writing skills.

In conclusion, the positive level of progression in the pre-post test as well as the formative tasks shows that the intervention carried out depicts the effectiveness of WBLL in teaching writing.

\section{Quality of writing:-}

This section presents the findings on the quality of writing through the mechanical aspects as presented in the table below. 
Table 5:-Analysis of quality in writing

\begin{tabular}{|l|l|}
\hline Mechanical aspects & Observer's notes \\
\hline Word-level & Ability to: \\
& $-\quad$ Spell correctly \\
& $-\quad$ Use lexical precisely \\
& $-\quad$ Punctuate correctly \\
& $-\quad$ General rule of grammar \\
\hline Sentence-level & Ability to: \\
& $-\quad$ Construct sentences following subject-verb agreement correctly \\
\hline Paragraph-level & Ability to: \\
& $-\quad$ Organise ideas accordingly \\
& $-\quad$ Discuss main ideas \\
& $-\quad$ Plan, draft, revise, edit. \\
\hline
\end{tabular}

Mechanical aspects of writing were observed through the students' answer in formative tasks carried out. Table 5 displays the emerging data observed through the three-tier of writing competency.

On word-level, participants displayed a fair amount of ability to spell, punctuate and by abiding the general rule of grammar like the verb of tenses. It can be seen during Cycle 1, formative 1, (C1F1) whereby participants interact with each other in Shared Sensory Writing activity. P5 described the object as 'ripe' to address the ripeness of the fruit. P10 described the object as 'yellow color' which allow P7 made further explanation by stating 'I like to eat ripe and yellow mango.'

On sentence-level, participants learn to construct simple sentences according to the subject/verb agreement. It can be seen during C1F2 in Chained Writing activity whereby P22 continue the story by stating, '...Then, the house in the middle of the jungle.' By the end of the activity, it is observed that P22 eventually self-corrected herself by amending her line as '..Then, the house is in the middle of the jungle' which comply with the rules of subject/verb agreement.

On paragraph-level, participants learn to organize their ideas accordingly. This can be seen during Cycle 2 in which they are required to produce 3-5 sentences per paragraph according to the topic. For instance, the teacher set the topic, 'If I have the power...'. Participants are expected to plan their writing by initiating, brainstorming and discussing main ideas which notable in the platform as P25 wrote that '...boys, what we want to be? Superhero, maybe?' P6 commented that 'I like Batman. Can we use that?' P9 asked, 'I don't remember his power. P6, can you tell us?' P6 responded, 'Let us Google' which implies that they were gathering information and material on the net to be used in their writing piece. Process writing is very detailed-oriented. The pupils displayed their ability to plan, draft, edit and revise their work in producing a single essay.

P5 wrote, 'If I have the power to be a Superhero, I will be Superman. I will help and protect the citizen of Malaysia. Great power comes with great responsibility'. This implies that participant able to link their supporting details with the main ideas, therefore making the organization of ideas logical and sequential. It is important to maintain the flow of ideas as it involves keeping the reader oriented to the central and subordinate ideas to create one complete paragraph.

Conclusively, pupils began to construct better pieces of writing through the integration of the intervention hence implies that the usability of WBLL in ESL classroom.

\section{Maturity in Writing:-}

This section presents the emerging data of maturity in writing as presented in table below.

Table 6:-Analysis of maturity in writing

\begin{tabular}{|l|l|}
\hline Maturity of writing & Observer's comment \\
\hline Stylistic dimension & Ability to: \\
& - Construct compound and complex sentences \\
& - Use lexical outside their required sight word \\
\hline
\end{tabular}




\begin{tabular}{|l|l|}
\hline & - Demonstrate varied writing style \\
\hline Cognitive dimension & $\begin{array}{l}\text { Ability to: } \\
\text { - Relate the issue in real-world situation } \\
\text { - Propose logical solution that can be used in real-life } \\
\text { - Understand abstract concept }\end{array}$ \\
\hline Moral dimension & -Moral reasoning \\
\hline
\end{tabular}

Table 6:-observes the participants' maturity of writing while answering the formative tasks. It is classified into three aspects: stylistic, cognitive and moral dimension.

Stylistic dimension concerned the linguistic ability of the participants. It is observed that participants construct lengthier sentences as from simple sentence to compound and complex sentence. For instance, P2 wrote 'It happens because the Sun and the Wind disappointed their mother, Star for not giving her any food' in Cycle 2 (C2F2) compared to 'One day, Raju is hungry. He went to hunting.' in Cycle 1 (C1F2). Most participants learn to voice their thoughts through writing by themselves rather than copying from the text read on the Internet to describe the character thus shows that they able to articulate their thoughts according to the tasks posed. This influence them to explore various writing styles, for instance, in C2F2, a few participants approached the task as an article, short story, and even a narrative. For instance, P7 interpreted the writing task, 'If I have power..' as a personal experience which noted that 'If I have power, I will save myself from bullies. I will be brave and fight.' It differs than P20 who interpreted the writing task as a short story, in which his response, 'If I have power, I will become a fierce lion. Everybody calls me The Lion King. I am the leader of the pack and all the animal. My pal, Mr. Roger the Rabbit will come to visit me every day.' Therefore, it enables the participants to explore the various style of writing as Wattpad.com is a platform to read others' material and get ideas from there.

Next, participants demonstrate the ability to use strong lexical like 'deceive' to illustrate 'lying' that precisely capture the essence of the issue. They also use lexical outside their required sight word which signifies the expansion of vocabulary range which is crucial in producing fluent writer.

Lastly, most of the product of write-up reflects the ability to relate the issue identified in a real-world situation hence proposing a logical solution to rectify the problem. This shows that they are ready to understand the abstract concept if taught in a longer period of time.

In conclusion, the intervention helped the participants to develop their maturity in writing by observing their improvement in linguistic, cognitive and moral dimension thus, making the WBLL possible to be used in teaching writing in ESL classroom.

\section{Corrective Feedback:-}

The corrective feedback is observed and recorded in the emerged themes derived from the observable learning behaviour while using the intervention in teaching writing and how it impacted the progression in writing skills as well as the interaction between the participants.

Table 7:-Corrective feedback analysis

\begin{tabular}{|c|c|c|}
\hline Mode & Type of constructive feedback & Observer's comment \\
\hline Researcher-participant & \multirow[t]{2}{*}{$\begin{array}{l}\text { Explicit correction } \\
\text { Recast }\end{array}$} & $\begin{array}{l}\text { The ability to: } \\
-\quad \text { Aware of own mistake } \\
-\quad \text { Self-correct independently }\end{array}$ \\
\hline Participant-participant & & $\begin{array}{l}\text { The ability to: } \\
-\quad \text { Identify their peers' } \\
\text { mistakes } \\
\text { - } \quad \text { Demonstrate active } \\
\text { investigation }\end{array}$ \\
\hline
\end{tabular}

\section{Explicit correction:-}

The researcher used explicit correction as response to learners' wrong sentences. In this process, the one who commented on the mistake need to provide explicit answers in the comment section. 
During the observation for the interaction between the participants, it showed that the participants had gone through the explicit correction process. Most of the participants were able to identify peers' error by highlighting and commenting on their friends' work which was uploaded on Wattpad.com. For instance, in Cycle 1, Activity 2, P1 constructed a sentence '.....Then I, Sarah and Lisa go to park yesterday'. It was observable that there is some grammatical mistake in the sentence constructed. P3 commented ,...'Sarah, Lisa and I is the right one'. This is further supported by P8 who corrected the sentence by stating '...'go' is wrong', you should use past tense to talk about past event or experiences and it was supposed to be 'went', the correct words for yesterday'. Based on this, the participants have provided an explicit correction to the error along with the justification. Not only that, observation also showed that all the participants eventually demonstrate an active participation by responding to the task set on Wattpad.com and discussing over the issues and topics vigorously rather than the passive participation demonstrated in the earlier sessions.

Therefore, throughout the process, the participants have demonstrated active investigation in providing explicit correction on their peers' mistake.

\section{Recast:-}

In Su (2016), Long (2007) thinks that recast is the most effective type of corrective feedback, since in the recast there are correct target language forms and communication won't be interrupted. By choosing this type of corrective feedback, the mistake made by the participants can be corrected immediately by providing the correct answers without having to ask the participants to justify their mistake. This will save more time as for the researcher and participants since the communication will not be interrupted by any question and answers session.

This process can be seen through the interaction between researcher and the participant. As the researcher is going through the participants' product, the researcher has commented on the grammatical error made by the participant in the comment column. For example, P1 wrote 'as I walks home from school, I heard a suspicious sound right behind me'. As it can be seen here, the participants used incorrect tense or singular noun in the sentence. Observation showed that the researcher has commented on the error in the comment section whereby it written as '..you are describing your past experience, so you should use past tense and the correct word is 'walked' instead of 'walks' and it should be in singular form. Based on this, the researcher straight away corrected the mistake without asking any explanation, and the participants were able to know their mistake on the spot.

Besides, this process also happened between the participants where they corrected on each other mistake. This can be observed while conducting the activity using WBLL, Wattpad.com. For example, when the researcher asked the participants to review the product of other groups, P1 from group 1, had written a comment on mistake done by participants from group 3. The mistake done was the incorrect use of plural from as it can be seen in the sentence, " My three brother have always been my own superhero'. In the comment section, P1 from group 1 had written '...you should add an 's' to the word 'brother'. From this, the participants have undergone the process of recast corrective feedback to give immediate comment and on the spot correction to other participants, hence, to have the ability to identify their peer's mistake.

In conclusion, participants evidently show progression in the process of writing by gaining corrective feedback from peers and researchers.

\section{Perception on WBLL:-}

\section{Analysis of group interview:-}

The analysis of the group interview is discussed in the table below:

Group interview analysis.

Table 8:-shows the issues emerged in the group interview.

\begin{tabular}{|l|c|}
\hline Issues emerged & Excerpt \\
\hline Perception of the intervention & $\bullet \quad$ It is fun \\
& $\bullet \quad$ It is so interesting \\
& - It is easy to use \\
& $\bullet \quad$ Wattpad is new to me but I started to like it. \\
\hline
\end{tabular}




\begin{tabular}{|c|c|}
\hline & $\begin{array}{l}\text { - At the tip of my finger and I can learn writing. } \\
\text { - This will help me to improve my writing } \\
\text { - I have so much fun when doing writing activity in the } \\
\text { 'Wattpad.com' } \\
\text { - Confuse. I don't know how to use it. I can only remember } \\
\text { it when doing together. }\end{array}$ \\
\hline Effects of the intervention & $\begin{array}{ll}\text { - } & \text { I can write better } \\
\text { - } & \text { I can do more } \\
\text { - } & \text { It helps me to write longer sentence than before. } \\
\text { - } & \text { I feel like I am improving in each lesson } \\
\text { - } & \text { I started to love writing }\end{array}$ \\
\hline Preference of the intervention in the future & $\begin{array}{l}\text { - I want to write more in 'Wattpad.com' } \\
\text { - Yes, I want to use it again in the future } \\
\text { - No, I think it is so hard to do it online, it is better to write } \\
\text { in the exercise book. } \\
\text { - Yes, I feel like I want to publish a short story in the } \\
\text { Wattpad.com } \\
\text { - I am confident to write longer now } \\
\text { I am not confident to use it. It is confusing. }\end{array}$ \\
\hline
\end{tabular}

Firstly, perception of intervention. Based on the interview, responses such as 'It is new to me, but I started to like it, 'at the tip of my finger and I can learn writing' and 'it is easy to use' indicates their positive feeling about the intervention. Furthermore, it is mutual that they feel 'it is fun', 'it' is so interesting' and 'I have so much fun when doing writing activity in the Wattpad.com' because it is believed that Wattpad.com will helps them 'to improve writing' because 'the writing activity in the Wattpad.com is so much fun'. This could also mean that having fun and experiencing enjoyment will be a 'motivator' causes to attend classes', 'a mechanism that 'encouraged concentration by learners and helped in the absorption of learning', and resulted in 'building a social connected learning environment'(Lucardie,2014). Thus, it is proof that it is prerequisite for the participants to improve their writing skills. However, P15 experienced uneasy feeling during the intervention. The uneasy feeling is described as 'confusing' because Wattpad.com is an integration of web-based language learning in teaching and learning process and it might affect the participant to be confused as it is not familiar with this kind of activity.

Next, effects of the intervention. Most participants agreed that they 'can write better' and write 'more' and 'write longer sentence than before' while engaging in the activity of Wattpad.com.' P16 said that 'I feel like I am improving in each lesson.' This displays the positive impact of the activity in the Wattpad.com as it helps the participants to be more engaged in the writing lesson. P7 gave answers like 'I started to love writing', suggesting that she feels more confident and believe she can do it better than before. It also shows that P7 is started to have intrinsic motivation to engaged herself with the activity in the Wattpad.com and thus it helps in boosting her writing skills.

Lastly, most of the participants agreed to 'use it again in the future' so that they can 'write more' after engaging themselves with writing activity in the Wattpad.com. Some of the participants even 'confident to write longer' and want to 'publish their own short story' in the Wattpad.com thus suggesting that they are really confident and feel that this platform do improve them in writing skills. However, some of them were 'not confident' to use Wattpad.com because it is 'confusing' and 'hard to do it online' and believe that 'writing lesson in the classroom' is much easier than using Wattpad.com which shows that these participants need more guidance and facilitator to help them to spark their interest of writing using the Wattpad.com.

In conclusion, the integration of WBLL in learning writing exhibits the positive attitudes among the participants. 


\section{Discussion:- \\ Impact on writing skills:-}

The main findings suggested that the integration of the writing modules developed and Wattpad.com makes WBLL possible in the primary ESL classroom as participants constantly showed improvement in writing skills through the formative tasks and pre-posttest. Mean score for the pretest indicated that the performance of writing skills is relatively low. However, the mean score for participants' from S1 and S3 is 100\% in their post-test 1 which marked the highest improvement in the group with 34\% change score. Besides, participants from S2 achieved $83 \%$ in the post-test 1 shows good progress with 17\% change score. Therefore, the positive level of progression in the preposttest shows that the intervention carried out depicts the effectiveness of WBLL in teaching writing. This is further supported by the findings from the formative task score. The positive progression that is noted in both cycles as all participants from three schools shows good progress of 5.7\%. S1 and S2 progressed from $88.6 \%$ in Cycle 1 to $94.3 \%$ in Cycle 2, and S3 showed progress from $94.3 \%$ to $100 \%$ shows that the participants showed improvement in Cycle 2 signifies that the modification made help to enhance writing skills. The consistent progression concludes that WBLL can be used to teaching writing in the ESL classroom. This is in line by Mashhadizadeh and Rezvani (2015) who found that WBLL places improvement in the confidence and writing proficiency. Librenjak (2016) further proves the effectiveness of WBLL as she noted language learners are more inclined toward technology in learning writing skills, especially among L2 learners. Yunus (2013) highlighted that ICT allows the students to create and share their works as well as using software to create graphics and multimedia projects so that they can write and do activities which enable Wattpad.com to serve as a platform for the participants to explore their writing skills creatively through modern technology in tandem of 21 st century classroom. In terms of writing style, participants are exposed to various writing styles from observing others' work. This allows the participants to widen their knowledge especially on how to construct better pieces of work by working and writing with the advanced writers in the group. Kwan and Yunus (2014) further supported the notion by highlighting the effect of collaborative writing in teaching writing using online platform as they noted that some students provided fixed formats to make discussions and writing more organized, others by thorough editing in the writing phase, thus implies that other higher-level skills of organization, writing coherence and editing are required to write effectively collaboratively.

\section{Impact on corrective feedback:-}

The continuum learning process in writing allows the participants to micro correct their mistakes in the process of writing using corrective feedback. This is evidently shown through the type of corrective feedback initiated by the researcher, for instance, recast allows the researcher to pinpoint mistakes once and encourages self-correctness independency. This is further supported in Su (2016), Long (2007) who thinks that recast is the most effective type of corrective feedback since in the recast there are correct target language forms and communication won't be interrupted. The mistake made by the participants can be corrected immediately by providing the correct answers without having to ask the participants to justify their mistake. Explicit correction, on the other hand, allows the participants to correct each other' mistakes and encourages peer reviews, hence giving the participant the autonomy to construct own knowledge and creating an encouraging norm in the classroom to be better without jeopardizing the participants' level of motivation to participate in the writing activities. This resonates with Yunus (2013) who mentioned that integration of ICT in teaching writing allows the teachers to validate the resources, facts, and figures given by the students as well as the students themselves can be further involved in the construction of knowledge and validating of sources and facts by questioning each other to ensure that the information posted is valid and legitimate. This group interdependency would further form a group dynamic over the period as Alikhani (2017) mentioned that if a group works as a cohesive group, cooperation and convergence can result in maximization of productivity. This suggested that overall, writing performance could have been better if the group is maintained for a longer period. Hence, it is found that participants improve writing skills from the corrective feedback given directly in the process of writing.

\section{Impact on motivation:-}

The interactive mode of Wattpad.com as well as the corrective feedback, allow the participants to enjoy learning writing skills. Most participants are reported to like the WBLL and think that it is fun to use it in the language classroom. Hence, it is suggested that the use of Wattpad.com elevates the level of motivation and send positive connotation in learning writing skills as Cong-Lem (2018) who found that WBLL can help to reduce L2 learners learning and making them become more active, motivated language learners. Teaching writing using Wattpad.com could attract participants' interest in learning writing due to the attractive interface and user-friendly as they can include various media such as pictures on their homepage. This is further supported by Lucardie (2014) who 
claimed that technological tools serve as a mechanism that 'encouraged concentration by learners and helped in the absorption of learning', and resulted in 'building a socially connected learning environment' which allow learning process to happen collaboratively and positively. The impact of using Wattpad.com in ESL classroom resonates with Said and Yunus (2013) who noted that the use of blog, which is another tool for WBLL, has helped students greatly in writing argumentative and descriptive essays, thus implied that WBLL is a powerful tool to practice writing and motivated the participants to enhance their writing skills. Furthermore, Wattpad.com held an international competition every year, therefore, participants are encouraged to polish their writing skills by reading others' material, not only from local writers but also worldwide prior entering the renowned competition. This global connectivity somehow motivated the participants to produce a better quality of writing by observing another part of the world writing pieces, hence, widen their insight towards writing styles and organization of ideas. The idea of getting recognized in the global writing community boost the participants' motivation to be at par of other writers. Carvo (2015) corroborated the idea of expectancy and increment level of motivation as he cited that learners who have the capacity to visualize themselves as future English speakers tend to have better achievement scores in order to achieve the Ideal L2 selves they aspire to be (Kim \& Kim, 2014). Therefore, it is proven that WBLL has affected participants positively.

\section{Conclusion:-}

As for the conclusion, it is proven that the use of WBLL, Wattpad.com has affected participants' in terms of their academic performance in writing skill as well as their positive attitudes towards WBLL.

This intervention has the integration of salient technology which is the use of Wattpad.com as the WBLL. In this research, it is considered as a global platform to teaching writing skills, and grooming independent and confident writers. This can be seen throughout the learning process which has been highlighted in the findings of this paper. The use of Wattpad.com has positively impacted the participants in terms of their participation both in doing the task as well as evaluating the other group's work. This whole process has making learning experience more authentic and well connected to real-life. Besides, the WBLL allows the teacher to adopt modern pedagogical approach by utilizing the innovation in meeting the needs of 21 st century learning. This helps to improve teachers' pedagogical practice instead of using the conventional teaching method. Aligned with that, this intervention has proven that participants were highly motivated to engage in each activity during the learning process. This can be seen through the result in findings as they have an active participation and deeply engaged when completing the task. This intervention also helps to nurture the participants to become a creative writer. As the participants doing the suggested interactive activity in class, they will find out that writing in L2 is not that difficult because the activities are able to provide them the enjoyment of writing in English. This will help to decrease their affective filter and reject their assumption that writing English is difficult. Not only that, it also provides the researcher with various of interactive writing activities so that they can provide a fun learning environment to the participants.

The implication of this intervention is that the module act as a resource for educators, with ideas ranging from teaching simple, compound and complex sentences to texts, to providing opportunities for writing linear and nonlinear texts. This is reflected from the module provided where the activities covered all the elements as well as considering the level of the participants. By doing this, it encourages a meaningful interaction between participants and researcher by brainstorming ideas and giving constructive feedback collectively. Since the activities cater all levels of the participants, each of them will be able to play a role and engage with the discussion. As this goes along, there will be more creative and independent writers, building portfolios of potential quality writers in the future.

\section{Reference:-}

1. Alavi, S., \& Amini, M. (2016). Language Trajectory through Corrective Feedback. International Journal Of Multicultural And Multireligious Understanding, 3(4), 7. doi: 10.18415/ijmmu.v3i4.53.

2. Alikhani, M., \& Bagheridoust, E. (2017). The Effect of Group Dynamics-Oriented Instruction on Developing Iranian EFL Learners' Speaking Ability and Willingness to Communicate. English Language Teaching, 10(11), 44.

3. Bartel, D. (2018). Good Writing Part III: Sentences and Paragraphs and the Importance of Location. Retrieved from https://campuspress.yale.edu/cnspy/2015/08/05/good-writing-part-iii-sentences-and-paragraphs-and-theimportance-of-location/

4. Chaudron, C. (1988). Second language classrooms: research on teaching and learning. Cambridge [Cambridge shire: Cambridge University Press. 
5. Cong-Lem, N. (2018). Web-Based Language Learning (WBLL) for Enhancing L2 Speaking Performance: A Review. Advances In Language And Literary Studies, 9(4), 143. doi: 10.7575/aiac.alls.v.9n.4p.143

6. Frey, B. (2018). The SAGE Encyclopedia of Educational Research, Measurement, and Evaluation.

7. Gorjian, B. (2012). Teaching Vocabulary through Web-Based Language Learning (WBLL) Approach. Procedia Technology, 1, 334-339. doi: 10.1016/j.protcy.2012.02.070

8. Graham, S., Hebert, M., \& Harris, K. (2015). Formative Assessment and Writing. The Elementary School Journal, 115(4), 523-547. doi: 10.1086/681947

9. Kwan, L. S., \& Yunus, M. M. (2014). Group participation and interaction in ESL Wiki collaborative writing among Malaysian gifted students. Asian Social Science, 11(2), 59.

10. Kim, T.-Y., \& Kim, Y.-K. (2014). A Structural Model for Perceptual Learning Styles, the Ideal L2 self, Motivated Behavior, and English Proficiency. System, 46, 14-27.

11. Lucardie, D. (2014). The Impact of Fun and Enjoyment on Adult's Learning. Procedia - Social And Behavioral Sciences, 142, 439-446. doi: 10.1016/j.sbspro.2014.07.696

12. Lia, M. (2017). Using An Observation Coaching Checklist to Provide Feedback to Teachers. Journal Of Catholic Education, 20(1), 311-323. doi: 10.15365/joce.2001162016

13. Lie, W., \& Yunus, M. (2018). Pen Pals Are Now in Your Finger Tips- A Global Collaboration Online Project to Develop Writing Skills. Creative Education, 09(15), 2491-2504. doi: 10.4236/ce.2018.915188

14. Librenjak, S., Kocijan, K., \& Janjić, M. (2016). Improving Students' Language Performance Through Consistent Use of E-Learning: An Empirical Study in Japanese, Korean, Hindi and Sanskrit. Acta Linguistica Asiatica, 6(2), 79-94.

15. Mashhadizadeh, D., \& Rezvani, E. (2018). Iranian EFL learners' attitude towards the use of WBLL approach in writing. Retrieved from http://consortiacademia.org/wpcontent/uploads/IJRSLL/IJRSLL_v5i3/1306-4595-1PB.pdf

16. Mohajan, H. (2018). Qualitative research methodology in social sciences and related subjects. Journal Of Economic Development, Environment And People, 7(1), 23. doi: 10.26458/jedep.v7i1.571

17. Nosrati, V. (2015). Teachers' and Learners' Attitudes toward the Use of Web-based Language Learning (WBLL). Journal Of Applied Linguistics And Language Research, Volume 2(Issue 8), 1-12. Retrieved from http://www.jallr.ir

18. Said, N. E. M., Yunus, M., Doring, L. K., Asmi, A., Aqilah, F., \& Li, L. K. S. (2013). Blogging to enhance writing skills: A survey of students' perception and attitude. Asian Social Science, 9(16), 95.

19. Sayyed Mohammad Alavi \& Mahboubeh Taghizadeh (2014) Dynamic Assessment of Writing: The Impact of Implicit/Explicit Mediations on L2 Learners' Internalization of Writing Skills and Strategies, Educational Assessment, 19:1, 1-16, DOI: 10.1080/10627197.2014.869446

20. Su, T., \& Tian, J. (2016). Research on Corrective Feedback in ESL/EFL Classrooms. Theory And Practice In Language Studies, 6(2), 439. doi: 10.17507/tpls.0602.29

21. Tort Calvo, E. (2015). Language learning motivation: the L2 motivational self system and its relationship with learning achievement.

22. Yunus, M. M., Nordin, N., Salehi, H., Sun, C. H., \& Embi, M. A. (2013). Pros and cons of using ICT in teaching ESL reading and writing. International education studies, 6(7), 119.

23. Yunus, M. M., Nordin, N., Salehi, H., Embi, M. A., \& Salehi, Z. (2013). The use of information and communication technology (ICT) in teaching ESL writing skills. English Language Teaching, 6(7), 1.

24. Yunus, M., \& Suliman, A. (2014). Information \& Communication Technology (ICT) Tools in Teaching and Learning Literature Component in Malaysian Secondary Schools. Asian Social Science, 10(7). doi: 10.5539/ass.v10n7p136. 